\title{
Consumer Adoption of Alipay in Malaysia: The Mediation Effect of Perceived Ease of Use and Perceived Usefulness
}

\author{
Tze Kiat Lui ${ }^{1,}$ Mohd Haniff Zainuldin ${ }^{2 *}$, Kwang-Jing Yii ${ }^{3}$, Lin-Sea Lau ${ }^{1}$, and \\ You-How Go ${ }^{1}$ \\ ${ }^{1}$ Faculty of Business and Finance, Universiti Tunku Abdul Rahman, 31900 Kampar, Perak, Malaysia \\ ${ }^{2}$ Faculty of Business and Accountancy, University of Malaya, 50603 Kuala Lumpur, Malaysia \\ ${ }^{3}$ Faculty of Business, Design and Arts, Swinburne University of Technology, 93350 Kuching, Sarawak, Malaysia
}

\begin{abstract}
Despite a growing trend in m-wallet services in Malaysia, the actual level of usage is considered low among all of the non-cash payment methods. The Malaysian government has taken a serious initiative in spurring the use of $\mathrm{m}$-wallets by providing a one-off RM30 incentive to all eligible Malaysians. As such, it is important to understand the motivations behind m-wallet usage by examining Alipay, which is favoured in the international, as well as Malaysian markets. This research investigates the effects of mobile payment knowledge, personal innovativeness, self-efficacy, convenience, and compatibility on the actual adoption of Alipay in Malaysia with perceived ease of use and perceived usefulness, as the mediators. Using importance-performance map analysis (IPMA) and Variance Accounted For (VAF), based on Partial Least Squares - Structural Equation

ARTICLE INFO

Article history:

Received: 27 March 2020

Accepted: 8 October 2020

Published: 26 March 2021

DOI: https://doi.org/10.47836/pjssh.29.1.22

E-mail addresses:

luitk@utar.edu.my (Tze Kiat Lui)

haniff.zainuldin@um.edu.my (Mohd Haniff Zainuldin)

kyii@swinburne.edu.my (Kwang-Jing Yii)

lauls@utar.edu.my (Lin-Sea Lau)

goyh@utar.edu.my (You-How Go)

*Corresponding author

Modelling (PLS-SEM) on 260 respondents, it was discovered that compatibility and perceived usefulness demonstrated high importance in improving the performance of Alipay adoption. The results also showed a direct effect between compatibility and mobile payment knowledge. Additionally, perceived usefulness was shown to be an essential mediator in influencing the impact of compatibility and convenience on the actual adoption of Alipay. This study has
\end{abstract}


produced essential policy recommendations for both mobile wallet providers and policymakers on how to further promote the adoption of mobile wallets in Malaysia.

Keywords: Alipay, importance-performance map analysis, mobile commerce, mobile payment, mobile wallet, technology acceptance model

\section{INTRODUCTION}

Mobile commerce is a growing trend in Malaysia, and it changes how consumers make payments for both goods and services, as well as for transferring money to each other. The increased use of mobile commerce will boost the adoption of mobile wallets ( $\mathrm{m}$-wallets), in facilitating electronic transactions between individuals or organisations. An m-wallet is an application installed typically on a smartphone and can be used to store money and perform financial transactions instantly (Madan \& Yadav, 2018). In comparison to traditional payment methods, m-wallets offer faster payment processing and require less effort. The number of m-wallet users in Malaysia keeps growing every year, as more service providers have penetrated the mobile payments market.

Despite the availability of numerous m-wallet providers, this has not assured a high rate of adoption, as compared to other payment methods, such as non-contact payment modes and credit cards (Garrett et al., 2014). Debit cards remain the top noncash payment method in Malaysia with 63\% of total users, as compared to m-wallets, with only $8 \%$ (Bank Negara Malaysia, 2019). According to Ondrus et al. (2009), $\mathrm{m}$-wallets are not widely accepted by users, particularly in the developing countries of Asia, although users are aware of their existence. M-wallet service providers must fully comprehend the determinants of m-wallet adoption for users, which will allow them to take practical measures to boost the usage of their m-wallet services. Besides, a better understanding of the determinants and adoption of m-wallets could assist the government in heightening m-wallet usage among Malaysians, which is in line with the blueprint of Malaysia's government ${ }^{1}$.

Understanding the impact of individual users' characteristics in using an m-wallet is critical, as the traits of users will affect their adoption behaviour for the technology. The adoption of an m-wallet may be subject to individuals who are sometimes concerned with different aspects of mobile payment services, including the perceived benefits and hindrances (Pal et al., 2015). When an m-wallet serves as a mechanism for payment, as individuals do not have full control over the application, it may raise concerns over its fidelity. Thus, this lack of control and virtuality of transactions has created high uncertainty in the cashless society (Yan \& Yang, 2015). In addition, users are also concerned about how much they are spending through $\mathrm{m}$-wallets, as no physical cash is present. Overspending may

1 To accelerate the country's migration towards electronic payments, in order to increase the efficiency of the nation's payment systems (Bank Negara Malaysia, 2019). 
happen, as some consumers believe that physical cash provides better control over their expenses (Nielson, 2019), subsequently leading to a lower level of self-efficacy to adopt $\mathrm{m}$-wallets.

This study pays attention to the world's largest mobile payment platform, namely; Alipay (Arvidsson, 2014), which is also the largest third-party mobile payment application in China (Pham \& Ho, 2015). Over the years, the number of registered Alipay users has increased rapidly (Bailey et al., 2017), which reinforces its popularity among m-wallet users. It is believed that Alipay makes network payments more dependable and narrows the perceived distance between merchants and consumers (Arvidsson, 2014). As one of the booming countries in implementing mobile payments, Malaysia has over 18,000 merchants who now accept Alipay nationwide. Malaysia was ranked 9 th out of 10 countries that dominated overseas spending on Alipay in 2018. Besides, a 106\% increase in spending, per Alipay user, and a 511\% increase in total spending, as compared to 2017 were also recorded in 2018 (Tan, 2018). Moreover, Alipay has partnerships with Malaysia's top listed banks, such as CIMB Bank, Maybank, and Public Bank, as well as a collaboration with Touch 'n Go Sdn Bhd. Despite there being many local $\mathrm{m}$-wallets available in the market, Alipay is recognised worldwide for its reliable financial services (Arvidsson, 2014) and accepted by numerous local and overseas stores, which gives a competitive advantage over other local m-wallets, which mostly focus on Malaysian stores only.
After the penetration of the mobile payments market by Alipay, the use of $\mathrm{m}$-wallets among Malaysian consumers has increased markedly among different age groups. The number of $\mathrm{m}$-wallet users aged between 25-34 years old increased by 5\% over six months in 2016 (Lim, 2017). Such an increase in mobile users will predominantly drive mobile payment growth in Malaysia. However, the ascent of the adoption of mobile payment services in Malaysia does not seem to be fully achievable, due to the rivalry of the numerous existing service providers. The fierce competition among $\mathrm{m}$-wallet providers in Malaysia has affected Malaysia's adoption rate of mobile payment services. Most local m-wallet providers in Malaysia have had to cede profits by offering zero merchant fees, incentives, discounts, and many have devised tactics to boost the adoption of their m-wallet applications (Pikri, 2018). Sen (2019) discovered that there was an extreme level of competition within the crowded m-wallet space in Malaysia, as many mobile wallet apps had been introduced, both from local and international providers.

It is important to address the issues highlighted above, regarding the adoption of m-wallets among Malaysians. Considering that Alipay is the world's largest m-wallet platform, it may be able to provide hints from the user perspectives, in terms of perceived ease of use (PEOU) and perceived usefulness (PU), by investigating the individual differences and the characteristics of mobile payments. Meanwhile, this study also bridges the gap between theory 
and practice by employing importanceperformance map analysis (IPMA), as an extension of PLS-SEM. IPMA can prioritise constructs and their indicators to improve a target construct (Ringle \& Sarstedt, 2016). This leads to a predominant benefit in the study of m-wallets, based on the specific important insights from individual differences and mobile payment systems, together with the mediators of the PEOU and PU.

\section{LITERATURE REVIEW}

In this section, the theoretical background of the study has been developed by a review of the literature on technology acceptance theories, mobile wallets, individual differences, and mobile payment system characteristics. A proposed research model and hypotheses have also been included.

\section{Theoretical Background}

Several research models, such as; Theory of Planned Behaviour (TPB), Theory of Reasoned Action (TRA), and Unified Theory of Acceptance and Use of Technology (UTAUT) can explain the usage behaviour of information systems. However, the Technology Acceptance Model (TAM) remains a pioneering and significant theoretical model that explains users' adoption of information systems (Davis et al., 1989). The TAM was initially developed by Davis (1989) and, since then, it has become one of the most prevalent theories, which has been broadly studied and applied in the IS field (Surendran, 2012). The TAM details the antecedents of computer acceptance across a wide range of end-user computing technologies and user populations (Rondan-Cataluña et al., 2015). Thus, it can anticipate user acceptance of certain information system applications. Although many new versions have emerged from the TAM, the two core beliefs, namely; PEOU and PU are the most relevant constructs, and both have been used in this study, as consumer actual adoption depends on whether a proposed system is favoured by the respondents (Taherdoost, 2018). Several recent pieces of literature have adopted PEOU and PU, as mediators in the TAM, such as in the studies by Gu et al. (2019), Moslehpour et al. (2018), and Nuryyev et al. (2020). Testing the mediating effects of PEOU and PU will demonstrate their important role in influencing the actual adoption of m-wallets.

In a similar research model, namely; UTAUT (Venkatesh et al., 2003), there are four important variables, which are the main determinants of users' behavioural intentions and usage behaviour. Some of the key constructs in UTAUT are somehow identical to the constructs in TAM. Nevertheless, UTAUT has moderating constructs that will moderate the impact of the four main variables towards usage intention and behaviour, thus, it cannot measure the direct impact of m-wallet adoption. For instance, S. Kim and Baek (2018) used TAM to examine the determinants of the behavioural intention to use mobile payments, as UTAUT had moderating effects that could affect the overall results. Besides, TAM has been continuously 
improvised by many scholars and extended to the usage of new information systems, such as m-wallet applications. Some recent literature, which have employed the TAM to examine human behaviour towards online payment acceptance includes Martens et al. (2017) and Ramos-de-Luna et al. (2016). In this study, TAM has been extended with several external factors that have been grouped into 2 dimensions, namely; individual differences and mobile payment systems.

\section{Mobile Wallet, Individual Differences, and Characteristics of Mobile Payment System}

With the continuous improvements that have been made in $\mathrm{m}$-wallets, it is undeniable that $\mathrm{m}$-wallets are acceptable in various business models for the convenience of merchants, including; small-sized business owners (Singh \& Sinha, 2020). Sorensen (2018) revealed that mobile wallets were capable of embedding various payment technologies, such as Near Field Communication (NFC) and QR codes to perform both in-store and remote payments. Hoofnagle et al. (2012) claimed that m-wallets were not used just for keeping payment data, but also for storing many kinds of loyalty cards and coupons, which offered additional benefits for users. Furthermore, the ubiquity of m-wallets enables users to make online transactions, anytime and anywhere, providing that the mobile device is connected to the Internet.

The study of the intention to use, or adopt, is commonly found in prior literature. The relationship between the intention to use and actual adoption has been confirmed in existing studies regarding mobile payment services, such as those by Jaradat and Al-Mashaqba (2014) and Rashed et al. (2014). Furthermore, some more recent studies have concentrated on the actual adoption of mobile payments, and have predominantly relied on the TAM, together with additional constructs, for example, H.Y. Kim et al. (2017), Martens et al. (2017), and Ramos-de-Luna et al. (2016). It is interesting to embed actual adoption as the main endogenous variable, to be tested with PEOU and PU. Besides, few studies have so far considered mobile payment system characteristics and individual differences in a single research model as the determinants of actual consumer adoption of m-wallets (C. Kim et al., 2010). Therefore, it is recommended to have multiple perspectives in examining $\mathrm{m}$-wallets and their diffusion; challenges, complexity, dynamism, marketlevel, as well as behavioural facets, to explain the diffusion of mobile payment systems (Ondrus et al., 2009).

Individual differences and system characteristics are two dimensions that are often included as external exogenous variables in the TAM to determine the information systems usage (Taherdoost, 2018). Existing literature has studied the link between individual characteristics and the acceptance of information systems using the TAM (Agarwal \& Prasad, 1998; Venkatesh, 2000). Those studies have confirmed the roles of individual differences in influencing users' behaviour with innovativeness, m-payment knowledge 
and self-efficacy, as constructs (C. Kim et al., 2010; Pal et al., 2015; Pham \& Ho, 2015). System characteristics are also vital, as the design characteristics of a system will bring significant effects towards the ease of use and usefulness of the system (Davis, 1989). The characteristics of mobile payment systems play an essential role in influencing the adoption of $\mathrm{m}$-wallets among individuals, however, this has rarely been studied empirically (C. Kim et al., 2010).

\section{Research Model}

The proposed research model used in this study consists of two dimensions with five constructs. All constructs will be examined directly with the actual adoption as well as its mediating effects with PEOU and/or PU as shown in Figure 1.

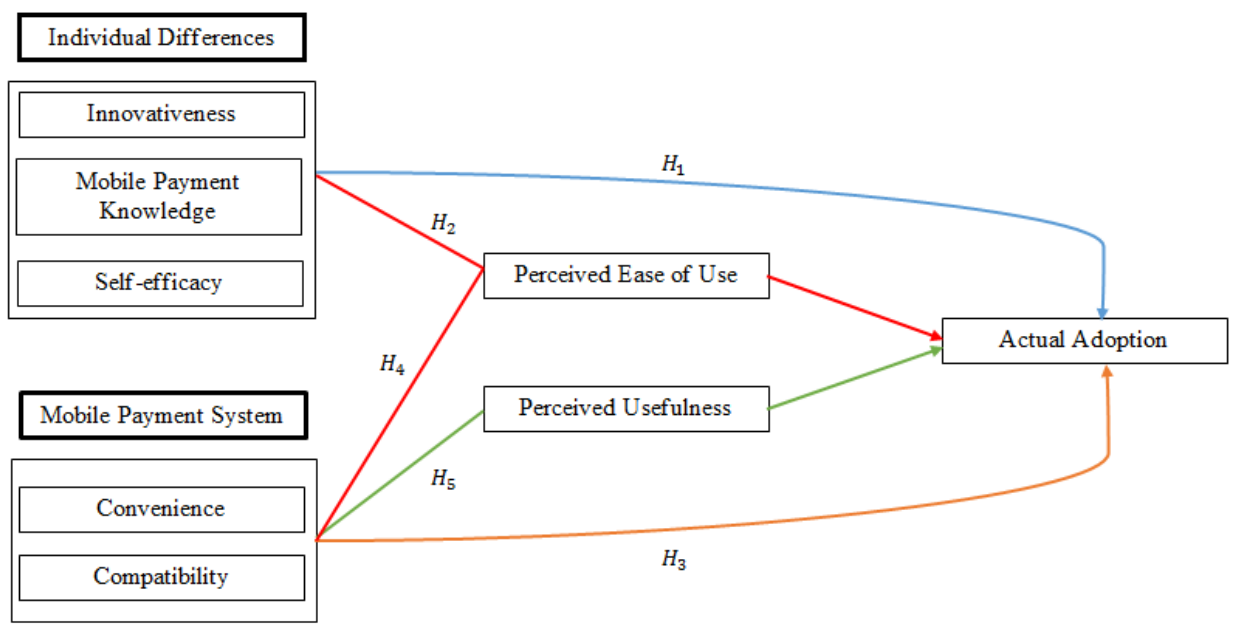

Figure 1. Research model (Adapted from C. Kim et al. (2010) and G. Wang et al. (2019))

Individual Differences. Individual differences are highly relevant to mobile commerce applications. C. Coursaris and Hassanein, (2002) and C. Kim et al. (2010) discussed that there was a huge growing interest in individual differences with mobile payment user behaviour studies. The individual differences consist of three constructs, which are; personal innovativeness, mobile payment knowledge and self-efficacy.

Personal Innovativeness. One of the individual differences used in this study was personal innovativeness, which can be referred to as the degree of willingness of an individual to try a particular innovation (Agarwal \& Prasad, 1998). It 
is believed that individuals with higher personal innovativeness will have higher positive perceptions and intentions to use a particular innovation. Pham and Ho (2015) investigated the relationship between personal innovativeness and the intention to adopt mobile payment services in Taiwan. A positive relationship was confirmed, in the sense that early adopters and individuals with innovativeness had a strong willingness to learn and use mobile payment services. The term innovative individuals usually refers to people with a high level of curiosity to discover and seek information with regards to a new idea. Other similar studies related to personal innovativeness include Li et al. (2014), Shaw (2015), and Yang et al. (2012). It is believed that innovative individuals find $\mathrm{m}$-wallets easy to use, as they have no issue with adapting to such new technology. Thus, this study offers the following hypotheses:

$\mathrm{H}_{1 \mathrm{a}}$ : Personal innovativeness will have a significant positive relationship with the actual adoption of Alipay in Malaysia.

$\mathrm{H}_{2 \mathrm{a}}$ : Personal innovativeness will be mediated by the PEOU towards the actual adoption of Alipay in Malaysia.

Mobile Payment Knowledge. A notion claims that m-wallets are relatively easy to use for individuals with higher mobile payment knowledge, as compared to individuals without such knowledge (C. Kim et al., 2010). Rogers (1995) proposed that sufficient knowledge from different channels was needed for individuals to be aware of the innovation and its benefits. $\mathrm{Li}$ et al. (2014) found that mobile payment knowledge was positive and significant to the behavioural intention of mobile payment adoption in China. They contended that consumers who possessed information and knowledge of mobile payment services tended to have a higher willingness to use mobile payment services. Other studies that have examined the relationship between mobile payments knowledge and PEOU include; C. Kim et al. (2010) and Pal et al. (2015). These studies believed that users, particularly the early adopters, who knew mobile payment services, would perceive them as easy to use, no matter how complex was the new technology. Thus, this study offers the following hypotheses:

$\mathrm{H}_{1 \mathrm{~b}}$ : Mobile payment knowledge will have a significant positive relationship on the actual adoption of Alipay in Malaysia.

$\mathrm{H}_{2 \mathrm{~b}}$ : Mobile payment knowledge will be mediated by the PEOU towards the actual adoption of Alipay in Malaysia.

Self-efficacy. Self-efficacy refers to an individuals' belief in their ability to perform a specific activity, or use an innovation (Bandura, 1997). Self-efficacy, in this study, refers to an individuals' belief that they have the skills and ability to use an m-wallet. Literature related to self-efficacy has been discussed in various domains of innovation adoption, such as the adoption of online shopping, mobile data services, and apparel retailing technologies. Nevertheless, it has been given less attention in the context of m-wallet adoption. Bailey et al. (2017) 
conducted a similar study using an extended version of the TAM in the US and they argued that self-efficacy would lead to the adoption of mobile payments through PEOU because users would be convinced about the capabilities of mobile payment services, such as having a user-friendly interface. This was in line with other studies, such as Shaw (2015) and Alalwan et al. (2016). Thus, this study offers the following hypotheses:

$\mathrm{H}_{1 \mathrm{c}}$ : Self-efficacy will have a significant positive relationship on the actual adoption of Alipay in Malaysia.

$\mathrm{H}_{2 \mathrm{c}}$ : Self-efficacy will be mediated by the PEOU towards the actual adoption of Alipay in Malaysia.

Mobile Payment Systems. In this study, we expected the characteristics of mobile payment systems to have a direct effect on PEOU and PU, as past literature has proved a strong relationship between the TAM and system characteristics (Davis, 1993; Pal et al., 2015; Venkatesh \& Davis, 2000). Four common constructs have been used in previous literature, namely; mobility, reachability, convenience, and compatibility. However, mobility and reachability were excluded in this study, as $\mathrm{m}$-wallets in Malaysia are considered new and the Internet infrastructure is not fully developed ${ }^{2}$.

2 There have been many complaints made by broadband users regarding dismal connectivity, although they are being promised improved services by the telco's, while the MCMC is currently concluding its National Fiberisation and Connectivity Plan (NFCP) (The Star, 2019).
Convenience. Convenience is a principal characteristic of mobile payments, which provide on-time utility and place to the consumers (C. Kim et al., 2010). Convenience refers to the situation where m-wallets, as a technology, will reduce any difficulty related to common tasks, therefore, making people's lives easier, so that users enjoy the benefits of using it (Obe \& Balogun, 2007). Using the Technology Readiness Index (TRI) model, Humbani and Wiese (2018) confirmed the positive and significant association between convenience and the adoption of mobile payments. The authors found that more male users were concerned with the convenience factors offered by mobile payment systems, which include the ability to integrate payments among different mobile payment applications. Other similar studies have also supported convenience as a vital construct that influences mobile payment adoption (Humbani \& Wiese, 2018; C. Kim et al., 2010; Pal et al., 2015; Shin, 2010). These studies believed that mobile payment systems had a high degree of usefulness and ease of use related to their features of portability and flexibility. As mobile devices and their user interfaces have improved over the years, this study offers the following hypotheses:

$\mathrm{H}_{3 \mathrm{a}}$ : Convenience will have a significant positive relationship on the actual adoption of Alipay in Malaysia.

$\mathrm{H}_{4 \mathrm{a}}$ : Convenience will be mediated by the PEOU towards the actual adoption of Alipay in Malaysia. 
$\mathrm{H}_{5 \mathrm{a}}$ : Convenience will be mediated by the PU towards the actual adoption of Alipay in Malaysia.

Compatibility. Compatibility refers to the degree of consistency on the perception of potential users towards a particular innovation with their experience, values, and needs (Rogers, 1995). Compatibility relies on how well the technology (mobile payments) is integrated into users' daily lives (Yang et al., 2012). Some extant literature has confirmed compatibility as among the consistent determinants for the adoption of mobile-technology-based services (Al-Jabri \& Sohail, 2012; Lin, 2011; Mallat, 2007). Based on a study concerning the adoption of mobile payments using NFC-enabled technology in China, Li et al. (2014) supported a positive significant impact of compatibility on the PU. They argued that users' concerns were related to the simplicity and versatility of mobile payments. Yang et al. (2012) found that users were concerned with the emotional appeal, rather than the functionalities offered in mobile payment applications, which supported the relationship between mobile payments and compatibility. Hence, this study offers the following hypotheses:

$\mathrm{H}_{3 \mathrm{~b}}$ : Compatibility will have a significant positive relationship on the actual adoption of Alipay in Malaysia.

$\mathrm{H}_{4 \mathrm{~b}}$ : Compatibility will be mediated by the PEOU towards the actual adoption of Alipay in Malaysia.
$\mathrm{H}_{5 \mathrm{~b}}$ : Compatibility will be mediated by the PU towards the actual adoption of Alipay in Malaysia.

\section{RESEARCH METHODS}

Survey research was used to analyse the linkages between the exogenous constructs and endogenous constructs through interceding variables. Cross-sectional data were used to observe specific phenomena at single points of time. Such correlational research design provided a huge amount of data through the real-world observation of m-wallet users.

\section{Sampling Design}

This study adopted a purposive sampling technique to identify qualified survey respondents who were individuals owning a smartphone with the Alipay application installed. The respondents must have been using Alipay for the previous three months to ensure that the data collected was compatible with the latest application version. The capital city of Malaysia, Kuala Lumpur was selected as the sampling location since Kuala Lumpur is the major economic, financial, and cultural hub of Malaysia. The penetration rate of mobile phones in Kuala Lumpur was 186 per 100 inhabitants, which was the highest among all of the cities in Malaysia (Malaysian Communications and Multimedia Commission [MCMC], 2017). Besides, the city itself has a fair balance of major ethnic groups to represent the general population characteristics of Malaysia. Furthermore, Kuala Lumpur is one of the 
cities that has achieved the digital maturity level of digital payments (Kadar et al., 2019). A minimum of 195 respondents was required, following the general thumb-rule (Hair et al., 1998). However, this study distributed 300 questionnaires, and a total of 260 questionnaires were successfully collected over 8 weeks.

\section{Research Instrument}

The multiple-item questions in the questionnaire were measured using a five-point Likert scale starting from 1 (strongly disagree) to 5 (strongly agree). Using a five-point Likert scale minimised confusion, improved response rates, and quality and ensured higher reliability. To begin with, a sample questionnaire was reviewed and pretested by several experts in the mobile commerce field. A pilot test was subsequently conducted with 30 respondents who were heavy Alipay users. The next step was to obtain ethical clearance from the University, whereby, the questionnaire would be reviewed and approved by the Ethical Clearance Committee (ECC).

\section{Data Analysis Methods}

Partial Least Square (PLS) Smart program version 3.0 (SmartPLS 3.0) was used to perform significance and normality testing through the t-test statistic from the bootstrapping procedure. PLS is highly recommended for this type of study because it is related to theory building and predictive applications (Gefen et al., 2000). It is also able to maximise the explanation on the variance of a model using a small sample size (Hair et al., 2013).

\section{RESULTS AND DISCUSSION}

\section{Descriptive Analysis}

The descriptive analysis examined the demographic profile of each of the respondents. Table 1 indicates that female users $(56.549 \%)$ possessed a higher level of adoption of Alipay in Malaysia, as compared to male users (43.46\%). Besides, young adults (aged 25-39 years old) and teenagers (aged below 24 years old) were keen to use Alipay, which represented the largest percentages of 50 percent and 42.31 percent, respectively. Meanwhile, none of the elderly, aged 55 years old and above, were using Alipay. This showed that younger consumers were familiar with mobile technology, while the elderly resisted using this form of new technology.

Besides, most of the sampled Alipay users were working adults (80\%) and hold a Bachelor's degree (83.85\%), indicating a high consciousness in using m-wallet. Surprisingly, the lower-middle-income group (RM3,000-RM4,500), and lowincome (RM1,501-RM3,000) occupied the highest rankings for the adoption of Alipay, which can be explained by these groups of consumers aiming to increase their savings by gaining discounts and promotions while using Alipay. However, most Alipay users (78.85\%), merely carried out transactions between one to three times per month. This illustrated that the adoption of Alipay in Malaysia was less popular, as compared to Alipay's usage in China. 
Table 1

Descriptive data

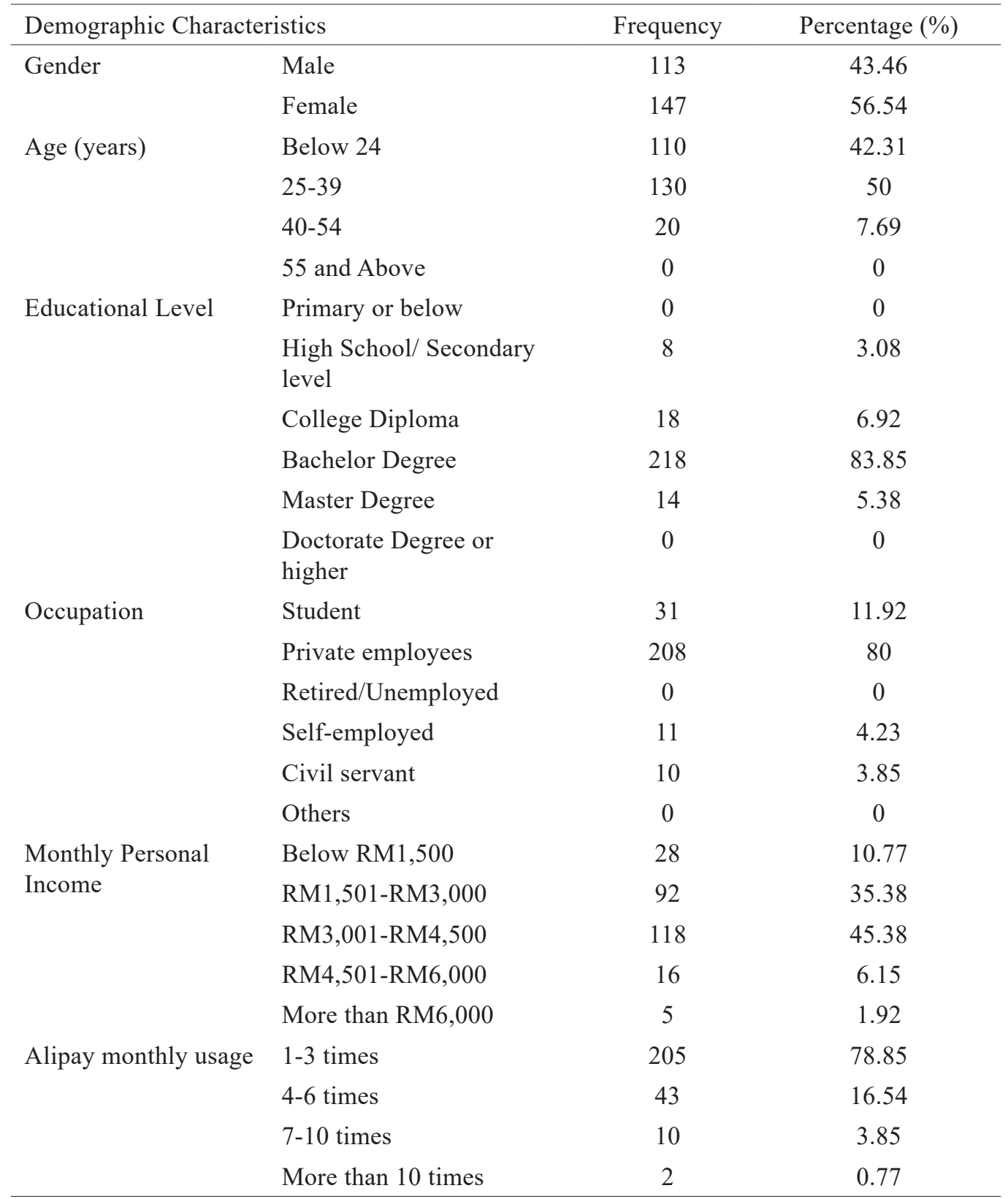




\section{Scale Measurement}

Outer Loading. Table 2 depicts that the majority of outer loadings for the respective indicators were greater than 0.70 , which is the accepted level recommended by Nascimento and Macedo (2016). The lowest outer loading values; PEOU1 (0.563) and
SE5 (0.568) were greater than 0.40 , thus, they did not need to be removed from the measurement models (Henseler et al., 2014). It showed that all of the latent variables explained a substantial part of each indicator's variance. The measurement model was also illustrated in Figure 2.

Table 2

Outer loading

\begin{tabular}{|c|c|c|c|c|c|c|c|c|}
\hline & $\mathrm{AA}$ & $\mathrm{COM}$ & $\mathrm{CON}$ & MPK & PEOU & PI & PU & SE \\
\hline AA1 & 0.736 & & & & & & & \\
\hline AA2 & 0.712 & & & & & & & \\
\hline AA3 & 0.761 & & & & & & & \\
\hline AA4 & 0.755 & & & & & & & \\
\hline AA5 & 0.725 & & & & & & & \\
\hline COM1 & & 0.721 & & & & & & \\
\hline COM2 & & 0.767 & & & & & & \\
\hline COM3 & & 0.784 & & & & & & \\
\hline COM4 & & 0.781 & & & & & & \\
\hline COM5 & & 0.649 & & & & & & \\
\hline CON1 & & & 0.705 & & & & & \\
\hline CON2 & & & 0.805 & & & & & \\
\hline CON3 & & & 0.801 & & & & & \\
\hline CON4 & & & 0.651 & & & & & \\
\hline CON5 & & & 0.691 & & & & & \\
\hline MPK1 & & & & 0.744 & & & & \\
\hline MPK2 & & & & 0.736 & & & & \\
\hline MPK3 & & & & 0.799 & & & & \\
\hline MPK4 & & & & 0.779 & & & & \\
\hline MPK5 & & & & 0.745 & & & & \\
\hline PEOU1 & & & & & 0.563 & & & \\
\hline PEOU2 & & & & & 0.741 & & & \\
\hline PEOU3 & & & & & 0.730 & & & \\
\hline
\end{tabular}


Table 2 (Continued)

\begin{tabular}{|c|c|c|c|c|c|c|c|c|}
\hline & AA & $\mathrm{COM}$ & $\mathrm{CON}$ & MPK & PEOU & PI & $\mathrm{PU}$ & SE \\
\hline PEOU4 & & & & & 0.709 & & & \\
\hline PEOU5 & & & & & 0.687 & & & \\
\hline PI1 & & & & & & 0.710 & & \\
\hline PI2 & & & & & & 0.666 & & \\
\hline PI3 & & & & & & 0.725 & & \\
\hline PI4 & & & & & & 0.717 & & \\
\hline PI5 & & & & & & 0.720 & & \\
\hline PU1 & & & & & & & 0.732 & \\
\hline PU2 & & & & & & & 0.741 & \\
\hline PU3 & & & & & & & 0.763 & \\
\hline PU4 & & & & & & & 0.741 & \\
\hline PU5 & & & & & & & 0.779 & \\
\hline SE1 & & & & & & & & 0.705 \\
\hline SE2 & & & & & & & & 0.646 \\
\hline SE3 & & & & & & & & 0.722 \\
\hline SE4 & & & & & & & & 0.705 \\
\hline SE5 & & & & & & & & 0.568 \\
\hline
\end{tabular}

\section{Construct Reliability and Validity Test}

Table 3 consists of the tests of composite reliability, convergent reliability, and discriminant reliability. These tests were applied to examine the internal consistency and reliability of the model. In Table 3, each of the respective constructs showed a high level of internal consistency, as the values of composite reliability were between .80 and .90 , which is greater than the suggested threshold of .60 (Hair et al., 2014). Cronbach's alpha is used to measure the internal consistency of a test, connected to the inter-relatedness of the items (Lunneborg, 1979). All of the reflective constructs were found to have a high level of interrelatedness between the items, as the values of Cronbach's alpha were greater than .70 .

The average variance extracted (AVE) was used to assess the convergent validity in the indicator constructs (Hair et al., 2014). Fornell and Larcker (1981) claimed that an AVE of .4, or below, was still acceptable, as long as the composite reliability value was greater than .60 . Thus, the values of the AVE for all of the reflective constructs had an adequate level of convergent validity, as shown in Table 3. 


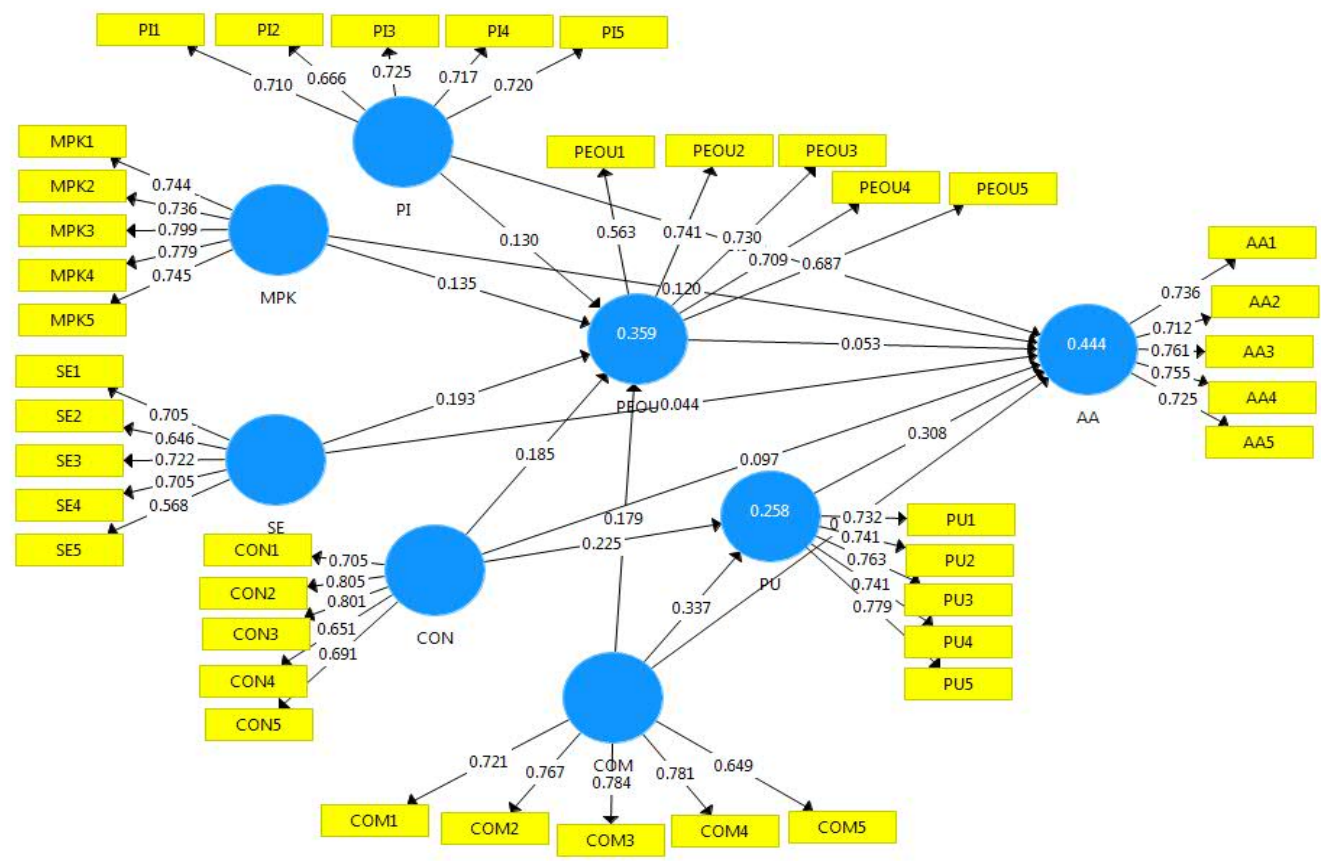

Figure 2. PLS-SEM measurement model

Table 3

Construct reliability and convergent validity

\begin{tabular}{lcccc}
\hline & Cronbach's Alpha & rho_A & $\begin{array}{c}\text { Composite } \\
\text { Reliability }\end{array}$ & $\begin{array}{c}\text { Average Variance } \\
\text { Extracted (AVE) }\end{array}$ \\
\hline AA & .795 & .803 & .857 & .545 \\
COM & .796 & .807 & .859 & .551 \\
CON & .782 & .784 & .852 & .537 \\
MPK & .820 & .827 & .873 & .579 \\
PEOU & .723 & .734 & .817 & .474 \\
PI & .755 & .761 & .834 & .501 \\
PU & .807 & .808 & .866 & .565 \\
SE & .704 & .686 & .803 & .451 \\
\hline
\end{tabular}

\section{Discriminant Validity Test}

Fornell -Larcker Criterion. The FornellLarcker criterion compares the square root of the AVE with the correlation of latent constructs. Hair et al. (2017) supported that the square root of each construct's AVE should be greater than the correlations with other latent constructs. Table 4 shows that the diagonal values of each variable 
were found to be greater than the offdiagonal inter-construct correlation values, respectively.

Cross Loading Criterion. The Crossloading criterion evaluates the impact of an indicator, in comparison with all of the other indicators (Hair et al., 2014). To determine the strong representation of the latent variable from the discriminant validity, the loading value of an indicator should be greater than all of the other indicators in the construct. Table 5 illustrates that the diagonal value of each indicator's crossloading was greater than the other indicators in the construct, respectively.

\section{Heterotrait-Monotrait Ratio (HTMT).} Kline (2011) asserted that HTMT values should fall below 0.85 for conceptually distinct constructs. Based on Table 6, the highest HTMT value was recorded as 0.798 , which fell below 0.85 . This illustrated that the true correlation between the two constructs was reliable, with no error.

Table 4

Fornell-Larcker criterion

\begin{tabular}{lcccccccc}
\hline & AA & COM & CON & MPK & PEOU & PI & PU & SE \\
\hline AA & 0.738 & & & & & & & \\
COM & 0.540 & 0.742 & & & & & & \\
CON & 0.469 & 0.619 & 0.733 & & & & & \\
MPK & 0.435 & 0.387 & 0.413 & 0.761 & & & & \\
PEOU & 0.467 & 0.470 & 0.467 & 0.430 & 0.689 & & & \\
PI & 0.280 & 0.361 & 0.326 & 0.528 & 0.376 & 0.708 & & \\
PU & 0.572 & 0.477 & 0.434 & 0.497 & 0.620 & 0.313 & 0.752 & 0.67 \\
SE & 0.371 & 0.402 & 0.375 & 0.416 & 0.424 & 0.258 & 0.402 & 1 \\
\hline
\end{tabular}

Table 5

Cross loading

\begin{tabular}{lcccccccc}
\hline & AA & COM & CON & MPK & PEOU & PI & PU & SE \\
\hline AA1 & 0.736 & 0.457 & 0.389 & 0.351 & 0.488 & 0.212 & 0.579 & 0.243 \\
AA2 & 0.712 & 0.333 & 0.256 & 0.168 & 0.187 & 0.176 & 0.307 & 0.248 \\
AA3 & 0.761 & 0.371 & 0.314 & 0.169 & 0.287 & 0.190 & 0.316 & 0.324 \\
AA4 & 0.755 & 0.386 & 0.395 & 0.387 & 0.381 & 0.212 & 0.486 & 0.276 \\
AA5 & 0.725 & 0.413 & 0.332 & 0.455 & 0.288 & 0.233 & 0.326 & 0.288 \\
COM1 & 0.369 & 0.721 & 0.558 & 0.346 & 0.368 & 0.309 & 0.365 & 0.331 \\
COM2 & 0.354 & 0.767 & 0.417 & 0.323 & 0.333 & 0.361 & 0.324 & 0.278 \\
\hline
\end{tabular}


Table 5 (Continued)

\begin{tabular}{|c|c|c|c|c|c|c|c|c|}
\hline & AA & $\mathrm{COM}$ & $\mathrm{CON}$ & MPK & PEOU & PI & PU & SE \\
\hline COM3 & 0.494 & 0.784 & 0.370 & 0.258 & 0.400 & 0.219 & 0.379 & 0.339 \\
\hline COM4 & 0.444 & 0.781 & 0.497 & 0.297 & 0.367 & 0.225 & 0.397 & 0.328 \\
\hline COM5 & 0.311 & 0.649 & 0.481 & 0.212 & 0.256 & 0.251 & 0.288 & 0.187 \\
\hline CON1 & 0.341 & 0.432 & 0.705 & 0.321 & 0.337 & 0.216 & 0.265 & 0.219 \\
\hline CON2 & 0.332 & 0.476 & 0.805 & 0.427 & 0.393 & 0.380 & 0.343 & 0.257 \\
\hline CON3 & 0.310 & 0.521 & 0.801 & 0.313 & 0.382 & 0.270 & 0.317 & 0.233 \\
\hline CON4 & 0.413 & 0.375 & 0.651 & 0.213 & 0.280 & 0.148 & 0.350 & 0.338 \\
\hline CON5 & 0.315 & 0.462 & 0.691 & 0.231 & 0.312 & 0.168 & 0.305 & 0.324 \\
\hline MPK1 & 0.248 & 0.336 & 0.358 & 0.744 & 0.352 & 0.477 & 0.338 & 0.322 \\
\hline MPK2 & 0.189 & 0.264 & 0.323 & 0.736 & 0.293 & 0.420 & 0.336 & 0.328 \\
\hline MPK3 & 0.429 & 0.291 & 0.337 & 0.799 & 0.305 & 0.415 & 0.373 & 0.293 \\
\hline MPK4 & 0.413 & 0.263 & 0.277 & 0.779 & 0.308 & 0.375 & 0.415 & 0.304 \\
\hline MPK5 & 0.317 & 0.323 & 0.290 & 0.745 & 0.377 & 0.344 & 0.416 & 0.346 \\
\hline PEOU1 & 0.155 & 0.255 & 0.330 & 0.333 & 0.563 & 0.292 & 0.228 & 0.215 \\
\hline PEOU2 & 0.278 & 0.246 & 0.301 & 0.204 & 0.741 & 0.270 & 0.377 & 0.277 \\
\hline PEOU3 & 0.364 & 0.439 & 0.395 & 0.378 & 0.730 & 0.406 & 0.361 & 0.331 \\
\hline PEOU4 & 0.348 & 0.294 & 0.290 & 0.287 & 0.709 & 0.137 & 0.555 & 0.298 \\
\hline PEOU5 & 0.409 & 0.339 & 0.283 & 0.263 & 0.687 & 0.173 & 0.581 & 0.315 \\
\hline PI1 & 0.242 & 0.280 & 0.302 & 0.316 & 0.202 & 0.710 & 0.201 & 0.134 \\
\hline PI2 & 0.249 & 0.201 & 0.100 & 0.192 & 0.127 & 0.666 & 0.153 & 0.117 \\
\hline PI3 & 0.159 & 0.158 & 0.227 & 0.319 & 0.278 & 0.725 & 0.139 & 0.169 \\
\hline PI4 & 0.135 & 0.288 & 0.246 & 0.347 & 0.320 & 0.717 & 0.268 & 0.177 \\
\hline PI5 & 0.219 & 0.324 & 0.252 & 0.596 & 0.348 & 0.720 & 0.307 & 0.277 \\
\hline PU1 & 0.407 & 0.358 & 0.367 & 0.360 & 0.493 & 0.142 & 0.732 & 0.370 \\
\hline PU2 & 0.418 & 0.378 & 0.415 & 0.396 & 0.512 & 0.196 & 0.741 & 0.365 \\
\hline PU3 & 0.437 & 0.378 & 0.326 & 0.421 & 0.401 & 0.295 & 0.763 & 0.235 \\
\hline PU4 & 0.396 & 0.337 & 0.244 & 0.304 & 0.448 & 0.302 & 0.741 & 0.248 \\
\hline PU5 & 0.486 & 0.338 & 0.268 & 0.379 & 0.474 & 0.247 & 0.779 & 0.289 \\
\hline SE1 & 0.258 & 0.243 & 0.208 & 0.380 & 0.217 & 0.249 & 0.258 & 0.705 \\
\hline SE2 & 0.255 & 0.196 & 0.151 & 0.196 & 0.125 & 0.057 & 0.178 & 0.646 \\
\hline SE3 & 0.231 & 0.262 & 0.242 & 0.209 & 0.210 & 0.118 & 0.244 & 0.722 \\
\hline SE4 & 0.235 & 0.267 & 0.168 & 0.244 & 0.284 & 0.152 & 0.281 & 0.705 \\
\hline SE5 & 0.247 & 0.318 & 0.387 & 0.309 & 0.445 & 0.225 & 0.320 & 0.568 \\
\hline
\end{tabular}


Table 6

Heterotrait-Monotrait Ratio (HTMT)

\begin{tabular}{lcccccccc}
\hline & AA & COM & CON & MPK & PEOU & PI & PU & SE \\
\hline AA & & & & & & & & \\
COM & 0.654 & & & & & & & \\
CON & 0.577 & 0.794 & & & & & & \\
MPK & 0.496 & 0.479 & 0.517 & & & & & \\
PEOU & 0.581 & 0.594 & 0.617 & 0.552 & & & & \\
PI & 0.362 & 0.463 & 0.409 & 0.640 & 0.481 & & & \\
PU & 0.677 & 0.588 & 0.541 & 0.603 & 0.798 & 0.388 & & \\
SE & 0.490 & 0.497 & 0.461 & 0.521 & 0.537 & 0.314 & 0.500 & \\
\hline
\end{tabular}

Model_Fit. Table 7 shows the model fit measures, such as SRMR, NFI, and RMS theta. The SRMR was estimated as .089, which was less than .10, hence, the model was considered to be a good fit. Besides, the NFI was recorded as .562 that aims to be closer to 1 . The value of.133 for RMS theta was closer to zero, which also proved a good model fit, where the correlations between the outer model residuals were relatively small.

Multivariate Skewness and Kurtosis. Table 8 indicates the estimation of the multivariate skewness and kurtosis, including excess kurtosis. In conjunction with the standard deviation, the kurtosis values were relatively smaller. On the other hand, the skewness indicates the negative, or left side, of the data distribution where the estimated values ranged from -0.706 to -2.05 .

Common Method Bias. According to Kock and Lynn (2012), the full collinearity
Table 7

Model fit

\begin{tabular}{lc}
\hline & Value \\
\hline SRMR & .089 \\
NFI & .562 \\
RMS_theta & .133 \\
\hline
\end{tabular}

VIF are generated to assess the common method bias in the model. Table 9 shows that the values of all of the VIFs from the full collinearity test were less than 3.3, whereby, the model was considered to be without common method bias.

\section{Importance-Performance Map Analysis (IPMA)}

Figure 3 shows that the two direct predecessors, COM and PU, possessed predominantly high importance. Based on Table 10, COM (0.406) was considered to have a higher importance than PU (0.343). However, COM had a relatively low performance of 62.689. Besides, the relatively high performance of PU also 
Table 8

Multivariate Skewness and Kurtosis

\begin{tabular}{lcccc}
\hline & Mean & $\begin{array}{c}\text { Standard } \\
\text { Deviation }\end{array}$ & Excess Kurtosis & Skewness \\
\hline AA & 3.477 & 0.757 & 0.352 & -0.561 \\
COM & 3.508 & 0.705 & 0.270 & -0.234 \\
CON & 3.456 & 0.747 & 0.846 & -0.706 \\
MPK & 3.689 & 0.741 & 0.624 & -0.506 \\
PEOU & 3.658 & 0.645 & 0.023 & -0.205 \\
PI & 3.605 & 0.656 & -0.001 & -0.207 \\
PU & 3.664 & 0.685 & 0.086 & -0.510 \\
SE & 3.718 & 0.603 & 0.481 & -0.391 \\
\hline
\end{tabular}

Table 9

Full Collinearity VIF

\begin{tabular}{lcccccccc}
\hline & AA & COM & CON & MPK & PEOU & PI & PU & SE \\
\hline $\begin{array}{l}\text { Common } \\
\text { Method Bias }\end{array}$ & 1.797 & 1.998 & 1.816 & 1.820 & 1.904 & 1.482 & 2.093 & 1.402 \\
\hline
\end{tabular}

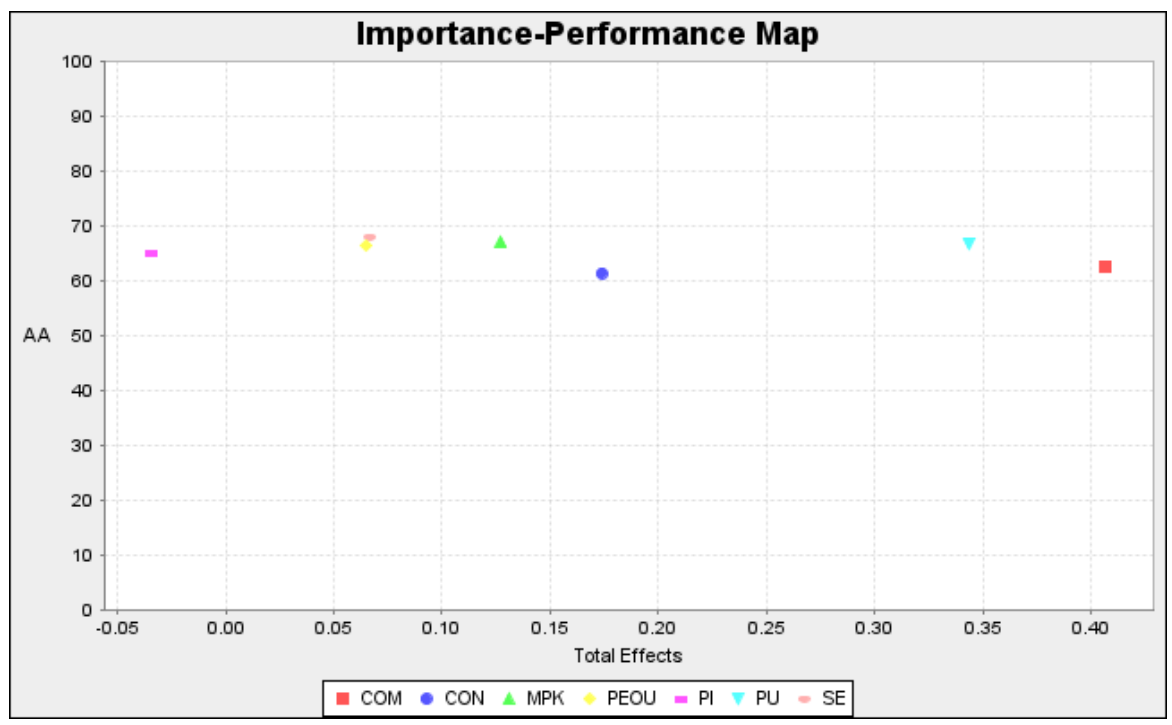

Figure 3. Importance-performance map (construct level) of target construct AA 
indicated that it should be focused to improve the performance of target construct AA. Therefore, managerial action should emphasise on improving the performance of COM towards AA, followed by PU, which would also mediate the effect between COM and AA. The PLS path model and IPMA results were illustrated in Figure 4.

The results show that compatibility was the strongest predictor for Alipay adoption, followed by PU. The importance of compatibility has been demonstrated in prior studies, such as S. Kim and Baek (2018) and Ozturk et al. (2016). It implied that when Malaysians perceived that the adoption of Alipay fitted well with the way they like to make payments, they would switch to mobile payments. This study also discovered the essential role of PU in enhancing Alipay usage in Malaysia, either directly or indirectly, as a strong mediator between compatibility and actual adoption. The results were in line with previous literature that suggested that the enhancement of job performance by using mobile technology would contribute to its adoption (Chi, 2018; Koksal, 2016).

Table 10

Data of importance-performance map for construct $A A$

\begin{tabular}{lcc}
\hline & Importance & Performances \\
\hline COM & 0.406 & 62.689 \\
CON & 0.174 & 61.399 \\
MPK & 0.127 & 67.227 \\
PEOU & 0.065 & 66.453 \\
PI & -0.034 & 65.126 \\
PU & 0.343 & 66.611 \\
SE & 0.067 & 67.943 \\
\hline
\end{tabular}

Figure 5 displays the indicator COM3 ("Alipay fits into my lifestyle"), which possessed a relatively high level of importance when concentrating on the construct COM, while performance still could be improved. Therefore, the Alipay company should fully comprehend the Malaysian lifestyle, in terms of geographical, cultural, and social diversity, to ensure the compatibility of its mobile wallet service. In fact, various past studies have looked into the relationship between lifestyle practices and consumers' behaviour or attitudes towards certain technologies (Axsen et al., 2012; C. K. Coursaris, \& Van Osch, 2015).

On the other hand, the indicator PU2 was discovered to be the most important indicator to improve the level of Alipay adoption for the PU construct. It is vital to enhance the ease of payment, based on the users' feeling of controlling and managing, the speed of digital interaction, and the 


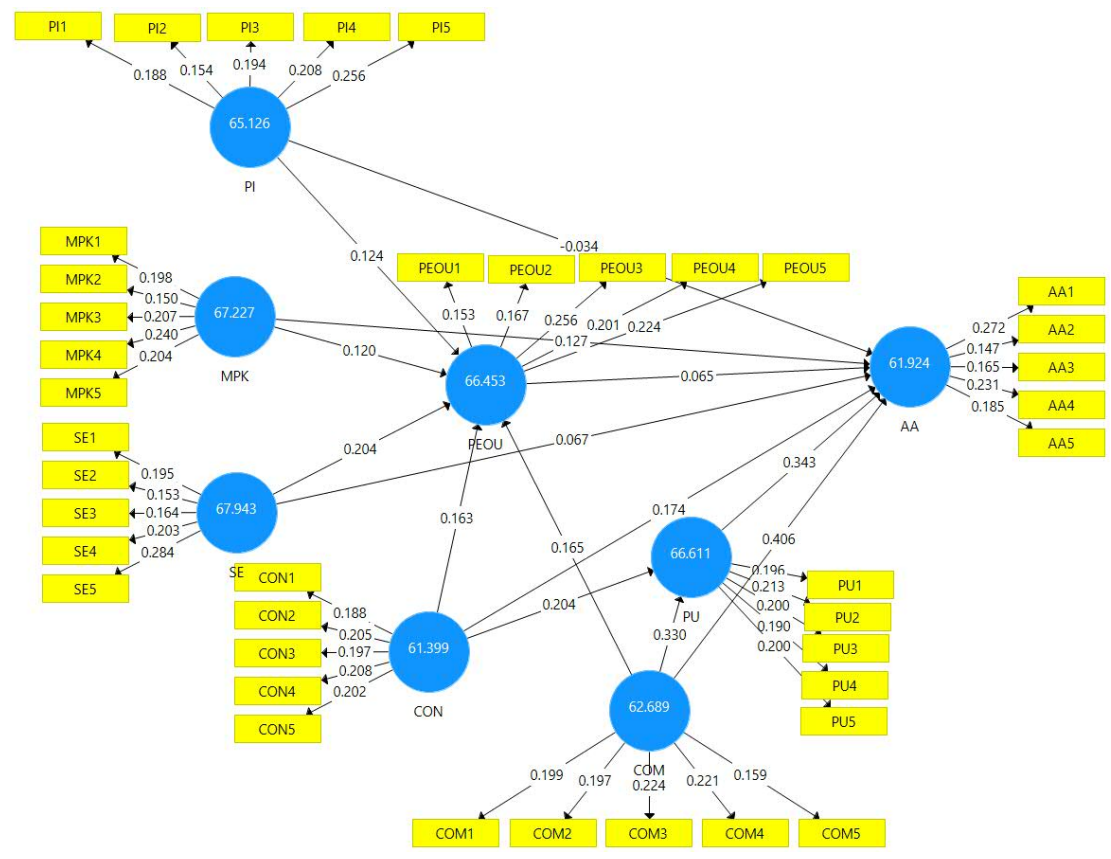

Figure 4. PLS path model and IPMA results

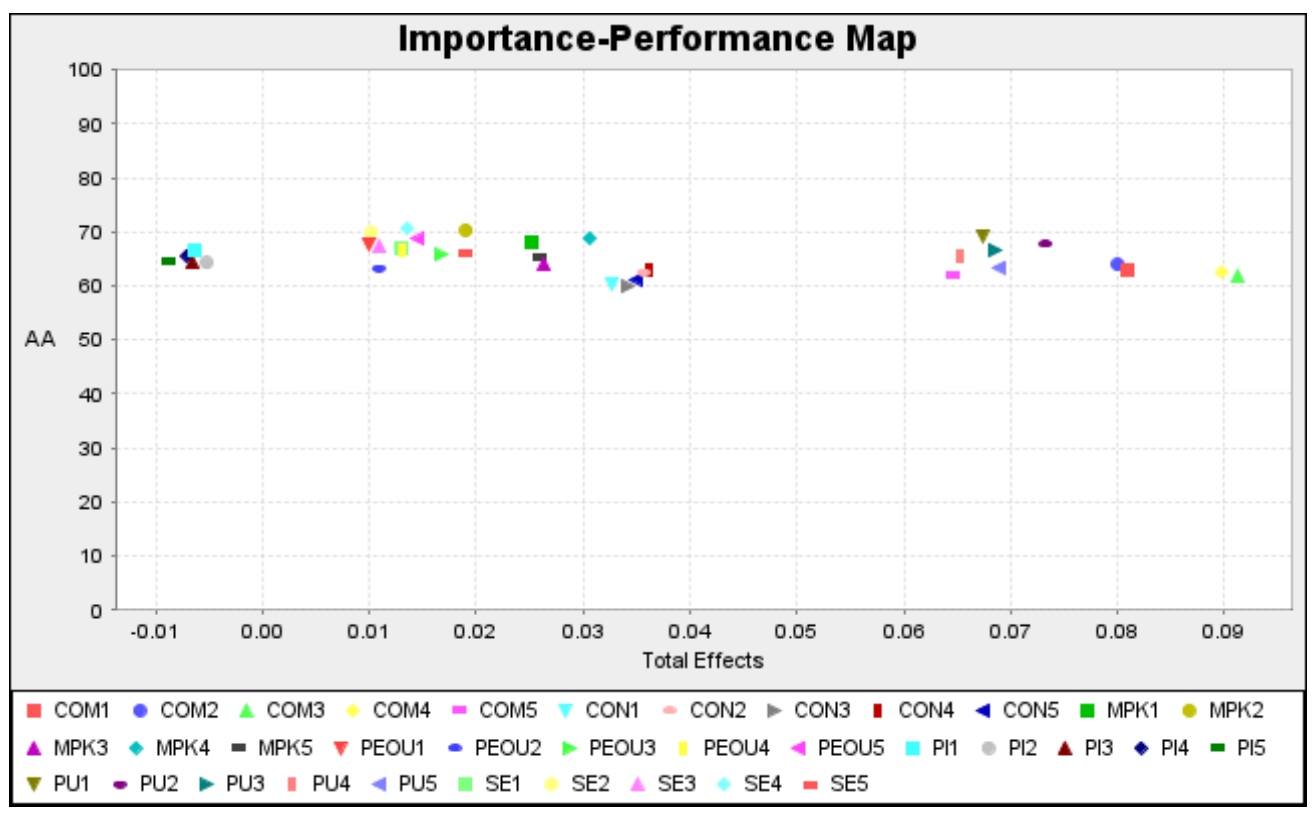

Figure 5. Importance-performance map (indicator level) of target construct AA 
receipt of notifications that complement their smartphone functions and features. According to previous studies, such as that of Jahmani et al. (2018), what facilities a technology can offer, influences users' satisfaction towards using that technology. This can, in turn, affect the actual usage of the said technology.

\section{Direct Effect}

Based on Table 11, only compatibility (COM) had a significant positive relationship with the actual adoption of Alipay, which indicated that consumers would select Alipay if the mobile wallet service was more integrated with their daily lives, or needs (Al-Jabri \& Sohail, 2012; Lin, 2018; Mallat, 2007). This finding was supported by Cheng (2015) and Isaac et al. (2019) who found that compatibility contributed a significant impact, leading to the high rate of adoption of high new technologies in the IS field.

Diversely, the hypothesis of $\mathrm{H} 1 \mathrm{~b}$ was supported at the $10 \%$ significance level, where mobile payment knowledge (MPK) might affect, but at a lower level, on the adoption of Alipay. This indicated that sufficient knowledge regarding the technology would cause consumers to use the mobile payment service ( $\mathrm{Pal}$ et al., 2015). This reflects more on the younger generation, rather than the elderly. Youngsters are more familiar with m-wallets and possess more knowledge about new technology, thus, encouraging them to adopt such technology. Such finding was supported by the descriptive analysis, as the majority of Alipay users were found to be young adults and teenagers.

The other factors, such as personal innovativeness, self-efficacy, and convenience were found to have no relationship with the actual adoption of Alipay. The findings were in agreement with Kabra et al. (2017) and Zainab et al. (2017) who revealed that personal innovativeness and self-efficacy did not affect the usage of technology. This may indicate that Malaysians are lacking confidence and skills in adopting mobile payment services due to inadequate exposure. Thus, the public should be educated on how to use mobile payment services so that the technology can become an integral part of people's lives.

Table 11

Hypothesis testing for direct effect

\begin{tabular}{|c|c|c|c|c|c|}
\hline \multirow[t]{2}{*}{ Hypothesis } & \multirow{2}{*}{$\begin{array}{c}\text { Path } \\
\text { Coefficient } \\
\text { (C) }\end{array}$} & \multirow[t]{2}{*}{$\begin{array}{l}\text { P-Values } \\
\text { (P) }\end{array}$} & \multicolumn{2}{|c|}{$\begin{array}{l}\text { Confidence Intervals } \\
\text { Bias Corrected }\end{array}$} & \multirow[t]{2}{*}{ Supportec } \\
\hline & & & $2.5 \%$ & $97.5 \%$ & \\
\hline $\begin{array}{l}\mathbf{H}_{1 \mathbf{a}} \text { : Personal innovativeness } \\
\text { will have a significant } \\
\text { positive relationship on the } \\
\text { actual adoption of Alipay in } \\
\text { Malaysia. }\end{array}$ & -.036 & .599 & -.168 & .096 & No \\
\hline
\end{tabular}


Table 11 (Continued)

\begin{tabular}{|c|c|c|c|c|c|}
\hline \multirow[t]{2}{*}{ Hypothesis } & \multirow{2}{*}{$\begin{array}{c}\text { Path } \\
\text { Coefficient } \\
\text { (C) }\end{array}$} & \multirow[t]{2}{*}{$\begin{array}{l}\text { P-Values } \\
\quad(\mathrm{P})\end{array}$} & \multicolumn{2}{|c|}{$\begin{array}{c}\text { Confidence Intervals } \\
\text { Bias Corrected }\end{array}$} & \multirow[t]{2}{*}{ Supported } \\
\hline & & & $2.5 \%$ & $97.5 \%$ & \\
\hline $\begin{array}{l}\mathbf{H}_{1 \mathbf{b}} \text { : Mobile payment } \\
\text { knowledge will have } \\
\text { a significant positive } \\
\text { relationship on the } \\
\text { actual adoption of } \\
\text { Alipay in Malaysia. }\end{array}$ & .120 & .069 & -.011 & .249 & $\begin{array}{c}\text { No (5\% sig. } \\
\text { level) } \\
\text { Yes }(10 \% \\
\text { sig. level) }\end{array}$ \\
\hline $\begin{array}{l}\mathbf{H}_{1 \mathrm{c}} \text { : Self-efficacy will } \\
\text { have a significant } \\
\text { positive relationship on } \\
\text { the actual adoption of } \\
\text { Alipay in Malaysia. }\end{array}$ & .044 & .540 & -.105 & .179 & No \\
\hline $\begin{array}{l}\mathbf{H}_{3 \mathbf{a}} \text { : Convenience } \\
\text { will have a significant } \\
\text { positive relationship on } \\
\text { the actual adoption of } \\
\text { Alipay in Malaysia. }\end{array}$ & .097 & .134 & -.036 & .218 & No \\
\hline $\begin{array}{l}\mathbf{H}_{3 \mathrm{~b}} \text { : Compatibility } \\
\text { will have a significant } \\
\text { positive relationship on } \\
\text { the actual adoption of } \\
\text { Alipay in Malaysia. }\end{array}$ & .257 & .000 & .128 & .396 & Yes \\
\hline
\end{tabular}

\section{Mediation Effect}

The mediation effect between the explanatory variables and the actual adoption of Alipay was determined based on a two-stage estimation that was, (1) significance of mediation effect on indirect effect and (2) strength of mediation effect using the Variance Accounted For (VAF). Based on Table 12, surprisingly, PEOU had no mediation effect on all of the explanatory variables and the actual adoption of Alipay. This might have been due to the Alipay wallet not being easily adopted in Malaysia. For example, the English language version of Alipay is not comprehensive for all Malaysians, as the application is mostly displayed in the Chinese language.

The mediator of the PU was found to partially mediate the relationship between convenience and compatibility towards the actual adoption of Alipay. The convenience variable was not directly related to the actual adoption of Alipay but was mediated by the PU to form a significant relationship. This implied that convenience might not be the main concern unless consumers believed that using Alipay would enhance their payment performance through mobile 
devices. Besides, compatibility was found to be a strong determinant of the adoption of Alipay in Malaysia. The partial mediation signified that the relationship between compatibility and the actual adoption of Alipay was also linked through the PU. Consumers who believed that the use of Alipay was to fulfil their needs would adopt it without hesitation. Besides, the result of the PU influencing actual adoption was consistent with the findings from previous studies (e.g. Liu et al., 2018; Z. Wang \& Dong, 2016), which demonstrated that new inventions with a higher PU tended to be easily accepted by consumers.

\section{Table 12}

Hypothesis testing for mediation effect

\begin{tabular}{|c|c|c|c|c|c|c|}
\hline \multirow[t]{2}{*}{ Hypothesis } & \multicolumn{2}{|c|}{ Indirect Effect } & \multicolumn{2}{|c|}{$\begin{array}{c}\text { Confidence } \\
\text { Intervals Bias } \\
\text { Corrected }\end{array}$} & \multirow[t]{2}{*}{$\begin{array}{l}\text { Variance } \\
\text { Accounted } \\
\text { For (VAF) }\end{array}$} & \multirow[t]{2}{*}{ Supported } \\
\hline & Coefficient & $\begin{array}{l}\text { P-values } \\
\text { (P) }\end{array}$ & $2.5 \%$ & $97.5 \%$ & & \\
\hline $\begin{array}{l}\mathbf{H}_{2 \mathrm{a}}: \text { Personal } \\
\text { innovativeness will } \\
\text { be mediated by the } \\
\text { PEOU towards the } \\
\text { actual adoption of } \\
\text { Alipay in Malaysia. }\end{array}$ & .007 & .587 & -.013 & .039 & - & No \\
\hline $\begin{array}{l}\mathbf{H}_{2 \mathrm{~b}} \text { : Mobile payment } \\
\text { knowledge will be } \\
\text { mediated by the } \\
\text { PEOU towards the } \\
\text { actual adoption of } \\
\text { Alipay in Malaysia. }\end{array}$ & .007 & .595 & -.013 & .045 & - & No \\
\hline $\begin{array}{l}\mathbf{H}_{2 \mathrm{c}} \text { : Self-efficacy will } \\
\text { be mediated by the } \\
\text { PEOU towards the } \\
\text { actual adoption of } \\
\text { Alipay in Malaysia. }\end{array}$ & .010 & .580 & -.022 & .052 & - & No \\
\hline $\begin{array}{l}\mathbf{H}_{4 \mathbf{a}} \text { : Convenience } \\
\text { will be mediated by } \\
\text { the PEOU towards } \\
\text { the actual adoption of } \\
\text { Alipay in Malaysia. }\end{array}$ & .010 & .582 & -.017 & .060 & - & No \\
\hline
\end{tabular}


Table 12 (Continued)

\begin{tabular}{|c|c|c|c|c|c|c|}
\hline \multirow[t]{2}{*}{ Hypothesis } & \multicolumn{2}{|c|}{ Indirect Effect } & \multicolumn{2}{|c|}{$\begin{array}{c}\text { Confidence } \\
\text { Intervals Bias } \\
\text { Corrected }\end{array}$} & \multirow[t]{2}{*}{$\begin{array}{l}\text { Variance } \\
\text { Accounted } \\
\text { For (VAF) }\end{array}$} & \multirow[t]{2}{*}{ Supported } \\
\hline & Coefficient & $\begin{array}{c}\text { P-values } \\
\text { (P) }\end{array}$ & $2.5 \%$ & $97.5 \%$ & & \\
\hline $\begin{array}{l}\mathbf{H}_{4 \mathrm{~b}} \text { : Compatibility } \\
\text { will be mediated } \\
\text { by the PEOU } \\
\text { towards the actual } \\
\text { adoption of Alipay } \\
\text { in Malaysia. }\end{array}$ & .009 & .595 & -.019 & .055 & - & No \\
\hline $\begin{array}{l}\mathbf{H}_{5 \mathbf{a}} \text { : Convenience } \\
\text { will be mediated by } \\
\text { the PU towards the } \\
\text { actual adoption of } \\
\text { Alipay in Malaysia. }\end{array}$ & .069 & .005 & .027 & .122 & $\begin{array}{c}39.20 \% \\
\text { (Partial } \\
\text { Mediation) }\end{array}$ & Yes \\
\hline $\begin{array}{l}\mathbf{H}_{5 \mathbf{b}} \text { : Compatibility } \\
\text { will be mediated by } \\
\text { the PU towards the } \\
\text { actual adoption of } \\
\text { Alipay in Malaysia. }\end{array}$ & .104 & .000 & .059 & .168 & $\begin{array}{c}28.03 \% \\
\text { (Partial } \\
\text { Mediation) }\end{array}$ & Yes \\
\hline
\end{tabular}

\section{CONCLUSION AND POLICY IMPLICATIONS}

Alipay has grown tremendously over the years and overtook PayPal as the world's largest mobile payment platform in 2013. Its introduction changed the users' behaviour in carrying out financial transactions, as they no longer needed to depend on physical cards to make payments. However, the penetration of mobile payment services, particularly m-wallets, in Malaysia is still considered low. In this regard, this study analysed the issue from the perspective of the actual adoption of Alipay, in the context of Malaysia.

This study provided the following findings. First, compatibility had a direct relationship with actual adoption. Similarly, knowledge about mobile payment services affected the actual adoption of mobile payment services directly. Second, the PU played the role of a mediator in influencing the effect of compatibility on actual adoption. Likewise, the linkage between convenience and actual adoption was mediated by the PU. Third, the PEOU did not act as a mediator in influencing the effects of innovativeness, mobile payment knowledge, self-efficacy, convenience, and compatibility on actual adoption. Fourth, personal innovativeness, mobile payment knowledge and self-efficacy were found to not contribute any significant effect on the adoption of m-wallets. 


\section{Theoretical Implications}

The present study adds to the limited literature available on the actual adoption of m-wallet by adapting the framework used by C. Kim et al. (2010) and G. Wang et al. (2019). This study serves as the forerunner in engaging structural equation modelling to focus on the mediation effect of consumers' PEOU and PU on m-wallet adoption. For this reason, this study fills the gap of comprehending the main factors that influence consumers' adoption of m-wallet and provides a better understanding of mobile payment platforms, in the context of Malaysia.

Additionally, each item of the constructs had specific importance. However, existing literature ignores this strand of research. In this regard, IPMA was used to measure the performance of each item; from significant constructs, such as perceived usefulness and compatibility. Hence, taking the performance of each indicator, from all of the constructs into consideration, was proven to be sound in providing diversified views and enhancing the existing knowledge about mobile payments adoption, particularly in the context of Alipay.

\section{Practical Implications}

To increase the actual adoption of m-wallet services in Malaysia, the following practical implications are suggested, based upon the study's findings. First, service providers are suggested to emphasise compatibility, to ensure that their services can meet users' current needs, values, and lifestyles. The service providers should incorporate additional features that could integrate with Malaysian lifestyles, so that, if users find these additional features are valuable and functional, they will start to adopt the mobile payment services.

Second, as knowledge of mobile payment services plays a vital role in stimulating actual adoption, it is essential to increase consumer awareness about the technology and its benefits. The service providers could improve consumers' knowledge of mobile wallets via various channels, such as roadshows, social media, and advertisements. It is necessary to educate the potential young users about m-wallet benefits. Apart from an effective payment tool, m-wallet could also be used to receive and send money instantly, with no additional charges, as well as to provide several money-saving opportunities via cashback, discounts, loyalty points, and rewards redemption.

Third, the government is suggested to provide incentives (e.g. tax relief/ exemption) to businesses in order to encourage them to conduct their business transactions using mobile payment services. As more businesses use mobile payment services, throughout the country, consumers' convenience in adopting the technology could also be enhanced. However, as shown by the results, convenience can only be translated into actual adoption with a high level of PU. In such a case, mobile wallet providers should improve the PU of their products, as only mobile wallets with a greater level of PU are likely to be adopted by consumers. 


\section{ACKNOWLEDGEMENTS}

We thank Chong Yee Lee for her assistance in data collection. This work was supported by the UTAR Research Fund 2018 Cycle 2, Universiti Tunku Abdul Rahman, Kampar, Perak [IPSR/RMC/UTARRF/2018-C2/Y03, 6200/Y62, 2018].

\section{REFERENCES}

Agarwal, R., \& Prasad, J. (1998). A conceptual and operational definition of personal innovativeness in the domain of information technology. Information Systems Research, 9(2), 204-215. https://doi.org/10.1287/isre.9.2.204

Alalwan, A. A., Dwivedi, Y. K., Rana, N. P., \& Williams, M. D. (2016). Consumer adoption of mobile banking in Jordan: Examining the role of usefulness, ease of use, perceived risk and self-efficacy. Journal of Enterprise Information Management, 29(1), 118-139. https://doi. org/10.1108/JEIM-04-2015-0035

Al-Jabri, I. M., \& Sohail, M. S. (2012). Mobile banking adoption: Application of diffusion of innovation theory. Journal of Electronic Commerce Research, 13(4), 379-391.

Arvidsson, N. (2014). Consumer attitudes on mobile payment services - Results from a proof of concept test. International Journal of Bank Marketing, 32(2), 150-170. https://doi. org/10.1108/IJBM-05-2013-0048

Axsen, J., TyreeHageman, J., \& Lentz, A. (2012). Lifestyle practices and pro-environmental technology. Ecological Economics, 82, 64-74. https://doi.org/10.1016/j.ecolecon.2012.07.013

Bailey, A. A., Pentina, I., Mishra, A. S., \& Mimoun, M. S. B. (2017). Mobile payments adoption by US consumers: An extended TAM. International Journal of Retail \& Distribution Management, 45(6), 626-640. https://doi.org/10.1108/IJRDM-08-2016-0144
Bandura, A. (1997). Self-efficacy: The exercise of control. Macmillan.

Bank Negara Malaysia. (2019). Payment systems. http:// www.bnm.gov.my/index.php? $\mathrm{ch}=\mathrm{ps} \& \mathrm{pg}=\mathrm{ps}$ mep_drv_toward\&ac $=193 \&$ lang $=$ en

Cheng, Y. M. (2015). Towards an understanding of the factors affecting m-learning acceptance: Roles of technological characteristics and compatibility. Asia Pacific Management Review, 20(3), 109-119. https://doi.org/10.1016/j. apmrv.2014.12.011

Chi, T. (2018). Understanding Chinese consumer adoption of apparel mobile commerce: An extended TAM approach. Journal of Retailing and Consumer Services, 44, 274-284. https://doi. org/10.1016/j.jretconser.2018.07.019

Coursaris, C., \& Hassanein, K. (2002). Understanding m-commerce: A consumercentric model. Quarterly Journal of Electronic Commerce, 3, 247-272.

Coursaris, C. K., \& Van Osch, W. (2015). Lifestyletechnology fit: Theorizing the role of selfidentity in IS research. Computers in Human Behavior, 49, 460-476. https://doi.org/10.1016/j. chb.2015.02.049

Davis, F. D. (1989). Perceived usefulness, perceived ease of use, and user acceptance of information technology. MIS Quarterly, 13(3), 319-340. https://doi.org/10.2307/249008

Davis, F. D. (1993). User acceptance of information technology: System characteristics, user perceptions and behavioral impacts. International Journal of Man-machine Studies, 38(3), 475-487. https://doi.org/10.1006/imms.1993.1022

Davis, F. D., Bagozzi, R. P., \& Warshaw, P. R. (1989). User acceptance of computer technology: A comparison of two theoretical models. Management Science, 35(8), 982-1003.

Fornell, C., \& Larcker, D. F. (1981). Evaluating Structural Equation Models with unobservable 
variables and measurement error. Journal of Marketing Research, 18(1), 39-50. https://doi. org/10.1177/002224378101800104

Garrett, J. L., Rodermund, R., Anderson, N., Berkowitz, S., \& Robb, C. A. (2014). Adoption of mobile payment technology by consumers. Family and Consumer Sciences Research Journal, 42(4), 358-368.

Gefen, D., Straub, D., \& Boudreau, M. C. (2000). Structural equation modeling and regression: Guidelines for research practice. Communications of the Association for Information Systems, 4, 7. https://doi.org/10.17705/1CAIS.00407

Gu, D., Khan, S., Khan, I. U., \& Khan, S. U. (2019). Understanding mobile tourism shopping in Pakistan: An integrating framework of Innovation Diffusion Theory and Technology Acceptance Model. Mobile Information Systems, 2019, 1490617. https://doi.org/10.1155/2019/1490617

Hair, J. F., Anderson, R. E., Tatham, R. L., \& Black, W. C. (1998). Multivariate data analysis. Prentice Hall International.

Hair, J. F., Hauff, S., Hult, G. T., Richter, N. F., Ringle, C. M., \& Sarstedt, M. (2017). A primer on Partial Least Squares Structural Equation Modelling (PLS-SEM) (2nd ed.). Sage Publication Inc.

Hair, J. F., Hult, G. T. M., Ringle, C. M., \& Sarstedt, M. (2014). A primer on partial least squares structural equation model (PLS-SEM). Sage Publication Inc.

Hair, J. F., Ringle, C. M., \& Sarstedt, M. (2013). Partial least squares structural equation modeling: Rigorous applications, better results and higher acceptance. Long Range Planning, 46(1-2), 1-12.

Henseler, J., Dijkstra, T. K., Sarstedt, M., Ringle, C. M., Diamantopoulos, A., Straub, D. W., Ketchen, D. J., Hair, J. F., Hult, G. T. M., \& Calantone, R. J. (2014). Common beliefs and reality about Partial Least Squares: Comments on Ronkko \& Envermann (2013). Organizational Research Methods, 17(2), 182-209. https://doi. org/10.1177/1094428114526928

Hoofnagle, C. J., Urban, J. M., \& Li, S. (2012). Mobile payments: Consumer benefits \& new privacy concerns. SSRN. https://papers.ssrn.com/sol3/ papers.cfm?abstract_id $=2045580$

Humbani, M., \& Wiese, M. (2018). A cashless society for all: Determining consumers' readiness to adopt mobile payment services. Journal of African Business, 19(3), 409-429. https://doi.or g/10.1080/15228916.2017.1396792

Isaac, O., Aldholay, A., Abdullah, Z., \& Ramayah, T. (2019). Online learning usage within Yemeni higher education: The role of compatibility and task-technology fit as mediating variables in the IS success model. Computers \& Education, 136, 113-129. https://doi.org/10.1016/j. compedu.2019.02.012

Jahmani, K., Fadiya, S. O., Abubakar, A. M., \& Elrehail, H. (2018). Knowledge content quality, perceived usefulness, KMS use for sharing and retrieval: A flock leadership application. VINE Journal of Information and Knowledge Management Systems, 48(4), 470-490. https:// doi.org/10.1108/VJIKMS-08-2017-0054

Jaradat, M. I. R. M., \& Mashaqba, A. M. A. (2014). Understanding the adoption and usage of mobile payment services by using TAM3. International Journal of Business Information Systems, 16(3), 271-296. https://doi.org/10.1504/ ijbis.2014.063768.

Kabra, G., Ramesh, A., Akhtar, P., \& Dash, M. K. (2017). Understanding behavioural intention to use information technology: Insights from humanitarian practitioners. Telematics and Informatics, 34(7), 1250-1261. https://doi. org/10.1016/j.tele.2017.05.010

Kadar, H. H. B., Sameon, S. S. B., Din, M. B. M., \& Rafee, P. B. A. (2019). Malaysia towards cashless society. In M. Othman, M. Abd Aziz, 
M. Md Saat, \& M. Misran (Eds.), Proceedings of the 3rd International Symposium of Information and Internet Technology (SYMINTECH 2018) (pp. 34-42). Springer, Cham. https://doi. org/10.1007/978-3-030-20717-5_5

Kim, C., Mirusmonov, M., \& Lee, I. (2010). An empirical examination of factors influencing the intention to use mobile payment. Computers in Human Behavior, 26(3), 310-322. https://doi. org/10.1016/j.chb.2009.10.013

Kim, H.-Y., Lee, J. Y., Mun, J. M., \& Johnson, K. K. P. (2017). Consumer adoption of smart in-store technology: Assessing the predictive value of attitude versus beliefs in the technology acceptance model. International Journal of Fashion Design, Technology and Education, 10(1), 26-36. https://doi.org/10.1080/1754326 6.2016 .1177737

Kim, S., \& Baek, T. H. (2018). Examining the antecedents and consequences of mobile app engagement. Telematics and Informatics, 35(1), 148-158. https://doi.org/10.1016/j. tele.2017.10.008

Kline, R. B. (2011). Principles and practice of structural equation modelling. Guilford.

Kock, N., \& Lynn, G. S. (2012). Lateral collinearity and misleading results in variance-based SEM: An illustration and recommendation. Journal of the Association for Information Systems, 13(7), 546-580.

Koksal, M. H. (2016). The intentions of Lebanese consumers to adopt mobile banking. International Journal of Bank Marketing, 34(3), 327-346. https://doi.org/10.1108/IJBM-03-2015-0025

Li, H., Liu, Y., \& Heikkilä, J. (2014). Understanding the factors driving NFC-enabled mobile payment adoption: An empirical investigation. PACIS 2014 Proceedings, 231. https://aisel.aisnet.org/ pacis $2014 / 231$
Lim, V. (2017, June 29). Asia: Increasing digital wallet usage amongst Malaysian consumers. RFi Group. https://www.rfigroup.com/rfi-group/ news/asia-increasing-digital-wallet-usageamongst-malaysian-consumers

Lin, H-F. (2011). An empirical investigation of mobile banking adoption: The effect of innovation attributes and knowledge-based trust. International Journal of Information Management, 31(3), 252-260. https://doi. org/10.1016/j.ijinfomgt.2010.07.006

Liu, Y., Hong, Z., Zhu, J., Yan, J., Qi, J., \& Liu, P. (2018). Promoting green residential buildings: Residents' environmental attitude, subjective knowledge, and social trust matter. Energy Policy, 112, 152-161. https://doi.org/10.1016/j. enpol.2017.10.020

Lunneborg, P. W. (1979). The vocational interest inventory: Development and validation. Educational and Psychological Measurement, 39(2), 445-451. https://doi. org/10.1177/001316447903900226

Madan, K., \& Yadav, R. (2018). Understanding and predicting antecedents of mobile shopping adoption: A developing country perspective. Asia Pacific Journal of Marketing and Logistics, 30(1), 139-162. https://doi.org/10.1108/ APJML-02-2017-0023

Martens, M., Roll, O., \& Elliott, R. (2017). Testing the technology readiness and acceptance model for mobile payments across Germany and South Africa. International Journal of Innovation and Technology Management, 14(6), 1750033. https://doi.org/10.1142/S021987701750033X

Malaysian Communications and Multimedia Commission. (2017). Handphone users survey 2017. https://www.mcmc.gov.my/resources/ statistics/hand-phone-surveys

Moslehpour, M., Pham, V., Wong, W-K., \& Bilgiçli, I. (2018). E-Purchase intention of Taiwanese consumers: Sustainable mediation 
of perceived usefulness and perceived ease of use. Sustainability, 10(1), 234. https://doi. org/10.3390/su10010234

Nascimento, J. C. H. P. D., \& Macedo, M. A. D. S. (2016). Modelagem de Equações Estruturais com Mínimos Quadrados Parciais: Um exemplo daaplicação do SmartPLS ${ }^{\circledR}$ em pesquisas em contabilidade [Structural Equation Models using Partial Least Squares: An example of the application of SmartPLS $\AA$ in accounting research]. Journal of Education and Research in Accounting, 10(3), 282-305. http://dx.doi. org/10.17524/repec.v10i3.1376

Nielsen. (2019, January 3). Cash or cashless? Malaysia's shifting payment landscape. Nielsen. https://www.nielsen.com/my/en/insights/ article/2019/cash-or-cashless-malaysiasshifting-payment-landscape/

Nuryyev, G., Wang, Y-P., Achyldurdyyeva, J., Jaw, B-S., Yeh, Y-S., Lin, H-T., \& Wu, L-F. (2020). Blockchain technology adoption behavior and sustainability of the business in tourism and hospitality SMEs: An empirical study. Sustainability, 12(3), 1256. https://doi. org/10.3390/su12031256

Obe, O. O., \& Balogun, V. F. (2007). Practice, trends and challenges of mobile commerce in Nigeria. Information Technology Journal, 6(3), 448-456. https://doi.org/ 10.3923/itj.2007.448.456

Ondrus, J., Lyytinen, K., \& Pigneur, Y. (2009). Why mobile payments fail? Towards a dynamic and multi-perspective explanation. 2009 42nd Hawaii International Conference on System Sciences, 1-10. https://doi.org/10.1109/hicss.2009.510

Ozturk, A. B., Bilgihan, A., Nusair, K., \& Okumus, F. (2016). What keeps the mobile hotel booking users loyal? Investigating the roles of selfefficacy, compatibility, perceived ease of use, and perceived convenience. International Journal of Information Management, 36(6), 1350-1359. https://doi.org/10.1016/j.ijinfomgt.2016.04.005
Pal, D., Vanijja, V., \& Papasratorn, B. (2015). An empirical analysis towards the adoption of NFC mobile payment system by the end user. Procedia Computer Science, 69, 13-25. https://doi.org/10.1016/j.procs.2015.10.002

Pham, T. T. T., \& Ho, J. C. (2015). The effects of product-related, personal-related factors and attractiveness of alternatives on consumer adoption of NFC-based mobile payments. Technology in Society, 43, 159-172. https://doi. org/10.1016/j.procs.2015.10.002

Pikri, E. (2018, July 20). How many e-wallets is too many wallets in Malaysia? Fintech Malaysia. https://fintechnews.my/17900/paymentsremittance-malaysia/e-wallets-digital-paymentmalaysia-saturated/

Ramos-de-Luna, I., Montoro-Ríos, F., \& LiébanaCabanillas, F. (2016). Determinants of the intention to use NFC technology as a payment system: An acceptance model approach. Information Systems and e-Business Management, 14(2), 293-314. https://doi. org/10.1007/s10257-015-0284-5

Ringle, C., \& Sarstedt, M. (2016). Gain more insight from your PLS-SEM results: The importance-performance map analysis. Industrial Management \& Data Systems, 116(9), 18651886. https://doi.org/10.1108/IMDS-10-20150449

Rashed, A., Santos, H., \& Aleryani, A. Y. (2014). Determinants of behavioral intention to mobile banking: Case from Yemen. MMEDIA 2013: The Fifth International Conferences on Advances in Multimedia, 96-99.

Rogers, E. M. (1995). Diffusion of innovations. Free Press.

Rondan-Cataluña, F. J., Arenas-Gaitán, J., \& Ramírez-Correa, P. E. (2015). A comparison of the different versions of popular technology acceptance models: A non-linear perspective. Kybernetes, 44(5), 788-805. https://doi. org/10.1108/K-09-2014-0184 
Sen, A. (2019, February 11). Malaysia's overpopulated e-wallet landscape: Deep pockets not enough. The Low Down. https://thelowdown.momentum. asia/malaysias-overpopulated-e-walletlandscape-deep-pockets-not-enough/

Shaw, N. (2015). The mediating role of perceived security: An empirical study of mobile wallet adoption in USA. In International Conference on HCI in Business (pp. 358-369). Springer, Cham.

Shin, D. H. (2010). Modeling the interaction of users and mobile payment system: Conceptual framework. International Journal of Human Computer Interaction, 26(10), 917-940.

Singh, N., \& Sinha, N. (2020). How perceived trust mediates merchant's intention to use a mobile wallet technology. Journal of Retailing and Consumer Services, 52, 101894. https://doi. org/10.1016/j.jretconser.2019.101894

Sorensen, E. (2018, May 31). Different types of mobile payments explained. Mobile Transaction. https:// www.mobiletransaction.org/different-types-ofmobile-payments/

Surendran, P. (2012). Technology acceptance model: A survey of literature. International Journal of Business and Social Research, 2(4), 175-178. https://doi.org/10.18533/ijbsr.v2i4.161

Taherdoost, H. (2018). A review of technology acceptance and adoption models and theories. Procedia Manufacturing, 22, 960-967. https:// doi.org/10.1016/j.promfg.2018.03.137

Tan, J. (2018, September 4). Malaysia and Singapore among Top 10 Alipay overseas spending markets. Marketing-Interactive. https://www.marketinginteractive.com/malaysia-and-singapore-amongtop-10-alipay-overseas-spending-markets/

Venkatesh, V. (2000). Determinants of perceived ease of use: Integrating control, intrinsic motivation, and emotion into the technology acceptance model. Information systems research, 11(4), 342365. https://doi.org/10.1287/isre.11.4.342.11872
Venkatesh, V., \& Davis, F. D. (2000). A theoretical extension of the technology acceptance model: Four longitudinal field studies. Management Science, 46(2), 186-204. https://doi.org/10.1287/ mnsc.46.2.186.11926

Venkatesh, V., Morris, M. G., Davis, G. B., \& Davis, F.D. (2003). User acceptance of information technology: Toward a unified view. MIS Quarterly, 27(3), 425-478. https://doi. org/10.2307/30036540

Wang, G., Putri, N. M., Christianto, A., \& Hutama, D. (2019). An empirical examination of characteristics of mobile payment users in Indonesia. Journal of Theoretical and Applied Information Technology, 97(1), 169-182.

Wang, Z., \& Dong, X. (2016). Determinants and policy implications of residents' new energy vehicle purchases: The evidence from China. Natural Hazards, 82(1), 155-173. https:// doi.org/10.1007/s11069-016-2185-4

Yan, H., \& Yang, Z. (2015). Examining mobile payment user adoption from the perspective of trust. International Journal of $u$ - and e-Service, Science and Technology, 8(1), 117-130.

Yang, S., Lu, Y., Gupta, S., Cao, Y., \& Zhang, R. (2012). Mobile payment services adoption across time: An empirical study of the effects of behavioral beliefs, social influences, and personal traits. Computers in Human Behavior, 28(1), 129142. https://doi.org/10.1016/j.chb.2011.08.019

Zainab, B., Bhatti, M. A., \& Alshagawi, M. (2017). Factors affecting e-training adoption: An examination of perceived cost, computer selfefficacy and the technology acceptance model. Behaviour \& Information Technology, 36(12), 1261-1273. https://doi.org/10.1080/014492 9X.2017.1380703 